\title{
Modeling the hydration process of bean grains coated with carnauba wax
}

\section{Modelagem do processo de hidratação de grãos de feijão revestidos com cera de carnauba}

\author{
Aline Almeida da Paixão ${ }^{1}$; Paulo Cesar Corrêa ${ }^{2}$; Fernanda Machado Baptestini ${ }^{3 *}$; \\ Sérgio Maurício Lopes Donzeles" ${ }^{4}$ Mayra Darliane Martins Silva Diniz ${ }^{5}$; \\ Rafael Leite de Freitas ${ }^{6}$
}

\begin{abstract}
Edible waxes are widely used to maintain foodstuff until they are consumed. However, some products may be subjected to industrial procedures, such as hydration, prior to their consumption. Hydration of a material is a complex process, which aims to reconstitute the original characteristics of a product when in contact with a liquid phase. An important agricultural product that requires this procedure is beans. Thus, the purpose of this work is to study the hydration process of beans (cultivar BRSMG Majestoso) in different temperatures and concentrations of carnauba wax, which is applied on the product surface. Beans with initial moisture content of $0.2015,0.1972$ and 0.1745 (d.b.) corresponding to treatments 0 (witness), 1 (wax diluted in water in the ratio 1:1), and 2 (carnauba wax, without dilution) were used. Later, these samples were imbibed in distilled water at temperatures of 20,30 and $40{ }^{\circ} \mathrm{C}$, for $15 \mathrm{~h}$. The temperature and the carnauba wax influenced the water absorption rate. The Peleg model described satisfactory experimental data and the Mitscherlich model presented biased residual distribution. The constants $\mathrm{C}_{1}$ and $\mathrm{C}_{2}$ of the Peleg model exhibited opposite behaviors with increasing temperatures in the hydration process.
\end{abstract}

Key words: Cultivar BRSMG Majestoso. Peleg model. Mitscherlich model.

\section{Resumo}

O uso de ceras comestíveis em produtos agrícolas é vastamente utilizado, de modo a conservar o alimento até o seu consumo. Contudo, alguns produtos podem sofrer algum processo industrial para o seu consumo, como a hidratação. A hidratação de materiais é um processo complexo que tem como objetivo reconstituir as características originais do produto, quando submetido ao contato com uma fase líquida. Um importante produto agrícola no qual requer esse processo é o feijão. Assim, objetivou-se com este trabalho estudar o processo de hidratação de grãos de feijão do cultivar BRSMG Majestoso para diferentes temperaturas e concentração de cera de carnaúba aplicada na superfície do produto. Foram utilizados grãos de feijão com teores de água de 0,$2015 ; 0,1972$ e 0,1745 (b.s.) correspondentes aos tratamentos 0 (testemunha), 1 (cera diluída em água na proporção de 1:1) e 2 (solução de cera de

${ }^{1}$ M.e, Engenharia Agrícola, Universidade Federal de Viçosa, UFV, Viçosa, MG, Brasil, E-mail: aline@itagro.com.br

2 Prof. Titular, UFV, Viçosa, MG, Brasil, E-mail: copace@ufv.br

3 Prof ${ }^{a}$ Adjunto, Universidade Federal do Espírito Santo, UFES, Alegre, ES, Brasil, E-mail: fernanda.baptestini@ufes.br; fbaptestini@yahoo.com.br

4 Pesquisador, Empresa de Pesquisa Agropecuária de Minas Gerais, EPAMIG, Viçosa, MG, Brasil. E-mail: slopes@epamig.br

5 Dra em Engenharia Agrícola, UFV, Viçosa, MG, Brasil. E-mail: mayra_darliane@hotmail.com

6 Eng ${ }^{\circ}$ Agrícola e Ambiental, UFV, Viçosa, MG, Brasil. E-mail: mardeminascontato@yahoo.com.br

"Author for correspondence

Received: Sept. 05, 2016 Approved: Apr. 20, 2017 
carnaúba, sem diluição), embebidos em água destilada, nas temperaturas de 20,30 e $40{ }^{\circ} \mathrm{C}$, durante 15 h. A temperatura e a cera de carnaúba influenciaram a taxa de absorção de água. O modelo de Peleg ajustou-se satisfatoriamente aos dados experimentais e o mesmo não pode ser afirmado para o modelo de Mitscherlich, por apresentar distribuição dos resíduos tendenciosa. As constantes $\mathrm{C}_{1}$ e $\mathrm{C}_{2}$ do modelo de Peleg apresentaram comportamento oposto com a elevação da temperatura de hidratação.

Palavras-chave: Cultivar BRSMG Majestoso. Modelo de Peleg. Modelo de Mitscherlich.

\section{Introduction}

Bean (Phaseolus vulgaris L.) is one of the traditional foods in the Brazilian diet and is an important source of protein. This source of protein is important, mainly because its cost is lower compared to products of animal origin. It also has socioeconomic importance since the productive chain of its cultivation employs a large number of workers.

One of the parameters used to check the quality of beans is the cooking time. This is related to how rapidly the grains absorb water before cooking. According to Omoto et al. (2009), the hydration process of grains is exhibited in the characterization of their physiological quality, in the extraction of some constituent of interest, in cooking, in the reduction or elimination of antinutritional factors, and in the improvement of digestibility. Hydration is a physical process that is directly related to the permeability characteristics of the hull (pericarp) and the properties of the constituent colloids of the grains (BEWLEY; BLACK, 1994; WOODSTOCK, 1988).

Studies on the kinetics of absorption and adsorption of water in agricultural products such as parboiled rice (BOTELHO et al., 2010), canary seedlings (LISBÔA et al., 2015), soybean (FRACASSO et al., 2014, 2015), and beans (RESENDE; CÔRREA, 2007) have evaluated the effect of temperature on the rate and amount of water diffused into the product. However, there are no studies to determine the effects of some types of coating, such as natural wax, on these variables.

The carnauba (Copernicia prunifera), a Brazilian palm tree from the Arecaceae family, is endemic in the northeastern semi-arid region and it offers a multitude of benefits to man, which are as follows. Its cultivation employs thousands of people; its roots are medicinally used as an effective diuretic; its fruits are rich in nutrients and, as such, are used in animal feed; its trunk provides quality timber for construction; and its haulm is used for handicraft products, soil fertilization, and wax extraction (CÂMARA SETORIAL DA CARNAÚBA, 2009).

Applying wax to agricultural products reduces water loss and gives them an attractive appearance after they are dried and polished. In addition, the wax film applied on the surface of the vegetable product presents different permeability rates to $\mathrm{O}_{2}$, $\mathrm{CO}_{2}$ and water vapor depending on the properties of the raw material, its concentration, and the film thickness, thus, allowing the product to be stored for a longer period.

Given the above, the purpose of this work is to model the kinetics of bean grain hydration of the cultivar BRSMG Majestoso for different temperatures and concentrations of the carnauba wax.

\section{Materials and Methods}

Bean grains of the cultivar BRSMG Majestoso, from the Carioca group, were harvested manually at the experimental field of the Agricultural Research Company of Minas Gerais (EPAMIG), in the city of Oratórios/MG. They were then purged with fumigants in order to avoid possible interferences due to infestations in the field. 
Grains with a water content of approximately 0.1481 d.b. were treated with the carnauba wax solution. For this procedure, the grains were divided into three batches of $25 \mathrm{~kg}$. The first batch was set aside as a control sample, the second batch had diluted wax applied in the ratio of 1:1 (carnauba wax solution/water), and the third batch had only the carnauba wax solution applied; the three batches were named as treatments 0,1 , and 2 , respectively.

The application of the carnauba wax solution was performed by spraying the grains with a $5 \mathrm{~L}$ trombone sprayer and conical jet nozzle. The grain mass was homogenized to ensure that the application of the solution would cover the entire surface of the beans. Subsequently, the grains were scattered in suspended yards for drying. The water contents for treatments 1 and 2 were 0.1547 and 0.1444 (d.b.), respectively.

After drying, the beans were stored in cotton bags. When the hydration test was performed, the water content of the bean grains was 0.2015 , 0.1972 and 0.1745 (d.b.) for treatments 0,1 and 2, respectively.

For the modeling of the hydration process, approximately $10 \mathrm{~g}$ of beans were soaked in $40 \mathrm{~mL}$ of distilled water at temperatures of 20, 30 and 40 ${ }^{\circ} \mathrm{C}$ for $15 \mathrm{~h}$. These temperatures were maintained by means of a BOD type chamber. The beans were placed on filter paper for 2 min to remove excess water. Then, their mass was determined using a digital scale, with a resolution of $0.01 \mathrm{~g}$, at time intervals of $1 \mathrm{~h}$. A set of three independent samples were used for each reading.

Two models were used in the modeling of the hydration process. The model proposed by Peleg (1988) (Equation 1) is often used to describe the processes of hydration of food products such as corn (BOTELHO et al., 2013) and chickpeas (TURHAN et al., 2002).

$$
U_{t}=U_{0} \pm \frac{t}{\left(C_{1}+C_{2} t\right)}
$$

where:

$\mathrm{U}_{\mathrm{t}}$ : water content at a given instant of time, decimal d.b.

$\mathrm{U}_{0}$ : water content of the product at zero time, decimal d.b.

$\mathrm{C}_{1}$ : Peleg rate constant, $100 \mathrm{~h} \mathrm{~kg}_{\mathrm{ms}} \mathrm{kg}_{\mathrm{a}}^{-1}$

$\mathrm{C}_{2}$ : Peleg capacity constant, $100 \mathrm{~kg}_{\mathrm{ms}} \mathrm{kg}_{\mathrm{a}}{ }^{-1}$

t: time, h.

The \pm sign presented in Equation 1 is because the model can be used in both absorption and adsorption $(+)$ processes as well as desorption (-) processes.

In addition to the Peleg model, we used the Mitscherlich model (Equation 2), described by Ratkowsky (1989), to describe the asymptotic regression curves in agricultural research.

$$
U_{t}=\alpha\left\{1-\exp \left[-k\left(t-t_{0}\right)\right]\right\}
$$

where:

$\alpha$ : water content when time tends to infinity, decimal d.b.

$\mathrm{k}$ : variation rate of water content over time, $\mathrm{s}^{-1}$

$\mathrm{t}$ : given instant of time, $\mathrm{s}$

$\mathrm{t}_{0}$ : initial time, $\mathrm{s}$.

To check how suitable the models were, the magnitude of the coefficient of determination $\left(\mathrm{R}^{2}\right)$, the average relative error $(\mathrm{P})$ (Equation 3 ), the estimated average error (SE) (Equation 4), and the residue distribution were taken into consideration.

$$
P=\frac{100}{n} \sum_{i=1}^{n} \frac{\left|Y_{i}-\hat{Y}_{i}\right|}{Y_{i}}
$$

$$
S E-\sqrt{\frac{\sum_{i=1}^{n}\left(Y_{i}-\hat{Y}_{i}\right)^{2}}{G L R}}
$$


where:

$\mathrm{Y}_{\mathrm{i}}$ : observed values

$\hat{Y}_{i}$ : model's estimated values

$\mathrm{n}$ : number of data

GLR: degree of freedom of the residue (in Portuguese "Grau de Liberdade do Resíduo") (number of data observed minus the number of the model's parameters).

\section{Results and Discussion}

Bean grains presented a characteristic behavior of absorbing water during the hydration process (Figure 1). At the beginning of the process, they showed a higher water absorption rate, with a tendency to decrease over time and to stabilize as the product approached its equilibrium water content (BOTELHO et al., 2010, 2013; JIDEANI; MPOTOKWANA, 2009; RESIO et al., 2006). Bello et al. (2004) reported that this behavior may be attributed to the rapid absorption of water by the capillaries of the outer layers of the pericarp, thus, promoting a rapid increase of water content in the product, that will tend to decrease with saturation. However, Botelho et al. (2013) argued that the high rates of initial water absorption may be caused by the high gradient of water content in the various tissues that constitute the grain, and in the environment.
It was noted that after $300 \mathrm{~min}(5 \mathrm{~h})$ of testing it becomes difficult to distinguish the effect of temperature on the absorption process. The temperature of $40{ }^{\circ} \mathrm{C}$ was the condition in which there was a higher rate of water absorption, which was independent of the assessed treatment. According to Muñoz et al. (2012), Vengaiah et al. (2012), and Yildirim et al. (2010, 2011), temperature is considered as the main factor affecting the absorption of water during hydration. The increase of the hydration temperature decreases the viscosity of the water, which directly influences the resistance of the fluid to drainage. Therefore, its decrease leads to easier diffusion of the water molecules in the capillaries of the product.

The initial and final values of water content of each treatment were close. The initial values for treatments 0,1 , and 2 were $0.2015,0.1972$ and 0.1457 (decimal d.b.), respectively. The final values were approximately $1.3014,1.3345$, and 1.3520 (decimal d.b.) for the samples of treatment 0; $1.2912,1.3217$, and 1.3332 (decimal d.b.) for the samples of treatment 1 ; and $1.2395,1.2600$, and 1.2898 (decimal d.b.) for the samples of treatment 2 at temperatures of 20,30 and $40{ }^{\circ} \mathrm{C}$ respectively. Thus, the carnauba wax influenced the absorption of water by the bean grains. This was because the wax acted as a barrier, making the water diffusion into the product more difficult. 
Figure 1. Water content of bean grains at different times and temperatures during hydration for treatments 0,1 , and 2 .
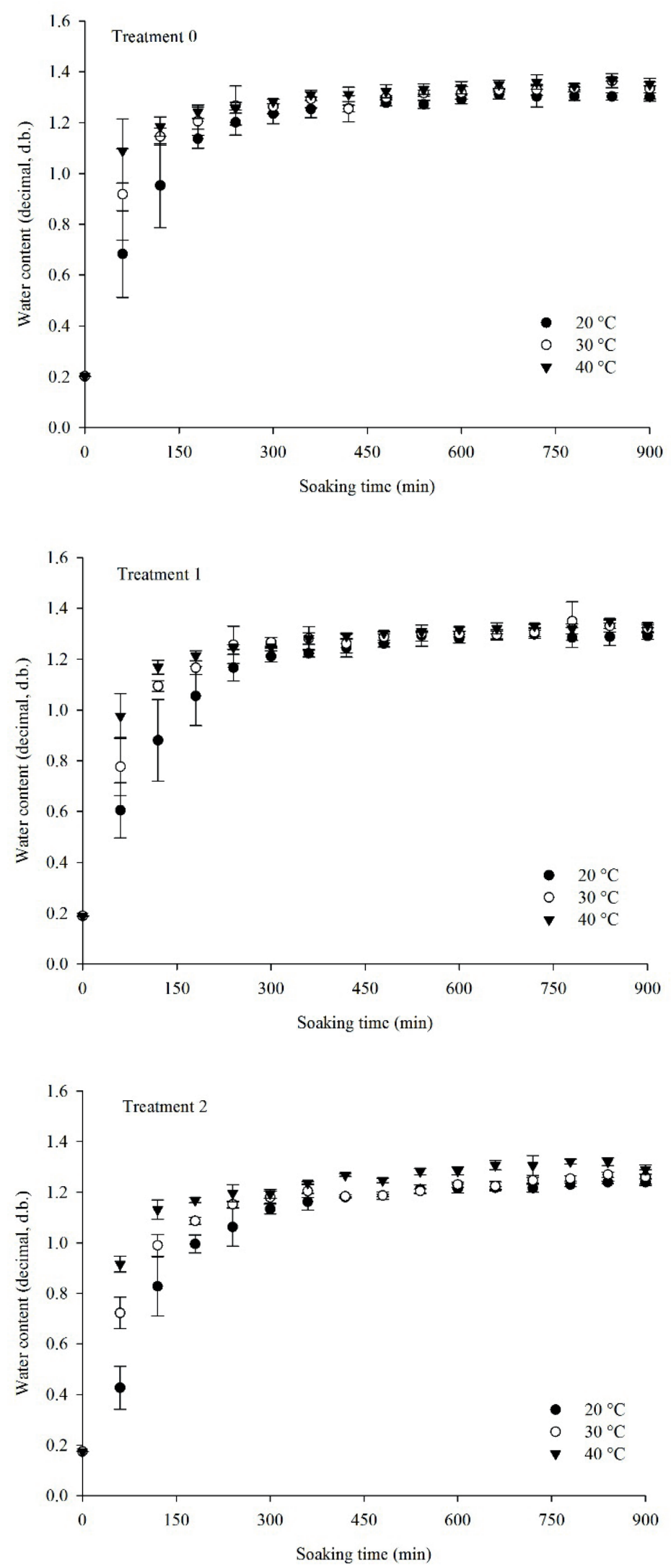
The performance of the Peleg model was evaluated by the magnitude of the statistical parameters (Table 1), which presented the values of the coefficient of determination above $92 \%$, p-value (probability of the null hypothesis to be true) for all conditions and coefficients lower than 0.0001, satisfactory values of the standard deviation of the estimate, and an estimated data variability of less than $10 \%$. According to Cunningham et al. (2007), the isolated coefficient of determination should not be used as a criterion for the evaluation of nonlinear models. However, the combination of these coefficients can be used to understand if the model was suitable. It was also noted that the values of
SE and $\mathrm{P}$ decreased with increasing temperatures, demonstrating that the best model represented experimental data for a higher temperature $\left(40^{\circ} \mathrm{C}\right)$. However, considering these statistical parameters by themselves does not guarantee the correct suitability of a model. It is necessary to analyze the distribution of the residue, because a model can have a biased distribution, being inefficient to represent the experimental data, even if presenting good statistical parameters. Therefore, Figure 2 was prepared, which shows that the residue distribution for bean grains was random for the temperatures of 30 and $40^{\circ} \mathrm{C}$ in all treatments.

Table 1. Average estimated error (SE), average relative error $(\mathrm{P})$, coefficient of determination $\left(\mathrm{R}^{2}\right)$ and coefficients $\left(\mathrm{C}_{1}\right.$ and $\mathrm{C}_{2}$ ) of the Peleg model obtained by adjusting the experimental data of the hydration of the bean grains, at different temperatures, for treatments 0,1 and 2 .

\begin{tabular}{lcccccc}
\hline Sample & $\begin{array}{c}\mathrm{T} \\
\left({ }^{\circ} \mathrm{C}\right)\end{array}$ & $\begin{array}{c}\mathrm{C}_{1} \\
\left(100 \mathrm{hg}_{\mathrm{ms}} \mathrm{kg}_{\mathrm{a}}^{-1}\right)\end{array}$ & $\begin{array}{c}\mathrm{C}_{2} \\
\left(100 \mathrm{~kg}_{\mathrm{ms}} \mathrm{kg}_{\mathrm{a}}^{-1}\right)\end{array}$ & $\mathrm{SE}$ & $\begin{array}{c}\mathrm{P} \\
(\%)\end{array}$ & $\mathrm{R}^{2}$ \\
\hline Treatment 0 & 20 & $0.961065^{* *}$ & $0.815130^{* *}$ & 0.038 & 2.62 & 0.9556 \\
& 30 & $0.498505^{* *}$ & $0.839146^{* *}$ & 0.020 & 1.18 & 0.9693 \\
& 40 & $0.305260^{* *}$ & $0.849002^{* *}$ & 0.014 & 0.77 & 0.9709 \\
\hline \multirow{3}{*}{ Treatment 1 } & 20 & $1.200381^{* *}$ & $0.793285^{* *}$ & 0.041 & 3.11 & 0.9583 \\
& 30 & $0.678437^{* *}$ & $0.821510^{* *}$ & 0.035 & 2.36 & 0.9440 \\
& 40 & $0.405216^{* *}$ & $0.846392^{* *}$ & 0.012 & 0.63 & 0.9857 \\
\hline \multirow{3}{*}{ Treatment 2 } & 20 & $1.519170^{* *}$ & $0.801368^{* *}$ & 0.060 & 5.23 & 0.9291 \\
& 30 & $0.785573^{* *}$ & $0.860174^{* *}$ & 0.026 & 1.89 & 0.9690 \\
& 40 & $0.470748^{* *}$ & $0.848447^{* *}$ & 0.020 & 1.25 & 0.9659 \\
\hline
\end{tabular}

${ }^{* *}$ p-value $<0.0001$ (probability of null hypothesis being true).

The Mitscherlich model is widely used in the area of soils, in describing a crop's response to an increase of some factor that has been limiting growth (Mitscherlich, 1909 quoted by) (HARMSEN, 2000), with no reference in the literature for the area of grains, and can become an option of adjustment in the modeling of grain hydration. However, while evaluating the model's performance using the statistical parameters presented, it was observed that the model had adjusted to the observed data for all temperature conditions and treatments in bean grains (Table 2). However, when the residual distribution was observed, this was not true for all situations (Figure 3). The residue distribution was randomized only in treatment 2 at a temperature of $20^{\circ} \mathrm{C}$. Thus, the model was not able to describe the process of hydration of bean grains.

Peleg rate constant rate $\left(\mathrm{C}_{1}\right)$ is related to the mass transfer rate. The smaller the values of $\mathrm{C}_{1}$, the higher the initial rates of water absorption 
(TURHAN et al., 2002). This parameter decreased with increasing temperature and this decrease was more expressive for the grains treated with higher concentrations of the carnauba wax. This coefficient can also be related to the diffusion coefficient (CUNNINGHAM et al., 2007). In addition, the higher the wax concentration, the higher the constant value for the same temperature indicating lower initial rates of water absorption. The behavior of constant $\mathrm{C}_{1}$ was observed by Botelho et al. (2010, 2013 ) in the analysis of hydration of rice and corn, by Cunningham et al. (2007) in modeling water absorption of pasta during soaking, and by Resende and Côrrea (2007) in the hydration of the bean seed.
Peleg capacity constant $\left(\mathrm{C}_{2}\right)$ is related to the maximum water absorption capacity, and the lower its value, the greater the total water absorption of the product. It was observed that this constant increased linearly with temperature; this was also verified by Jideani and Mpotokwana (2009) for temperatures between 25 and $75{ }^{\circ} \mathrm{C}$, demonstrating that the rate of water absorption increases with the decrease in absorption capacity and increase in temperature. However, for most works following this line of research, it was observed that the constant decreased when the temperature increased (BOTELHO et al., 2010; CUNNINGHAM et al., 2007; RESENDE; CÔRREA, 2007).

Figure 2. Residue distribution of the Peleg model for bean grains at different hydration temperatures for treatments 0,1 , and 2 .

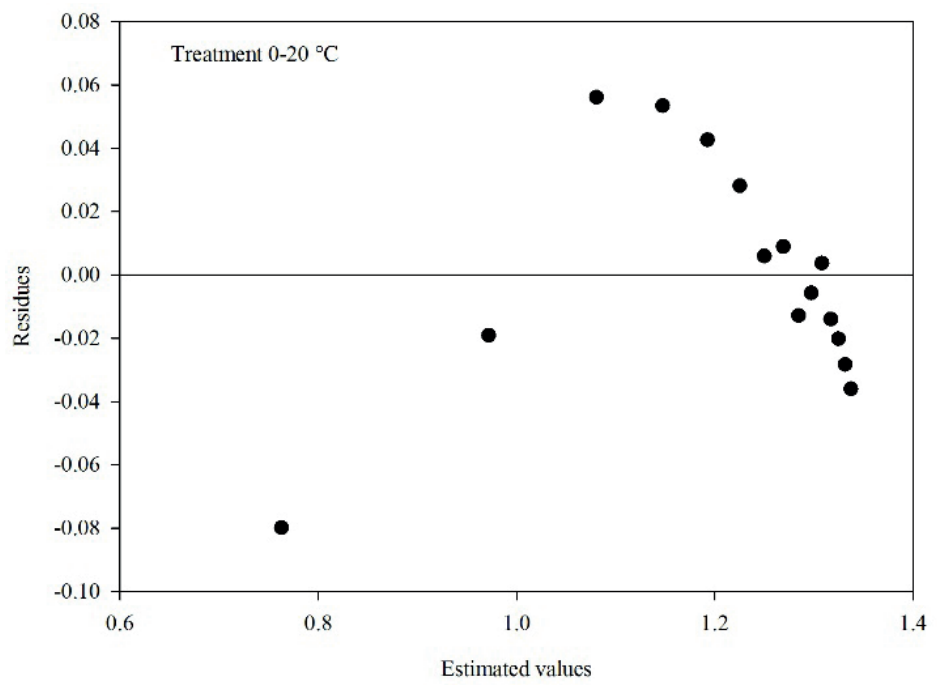



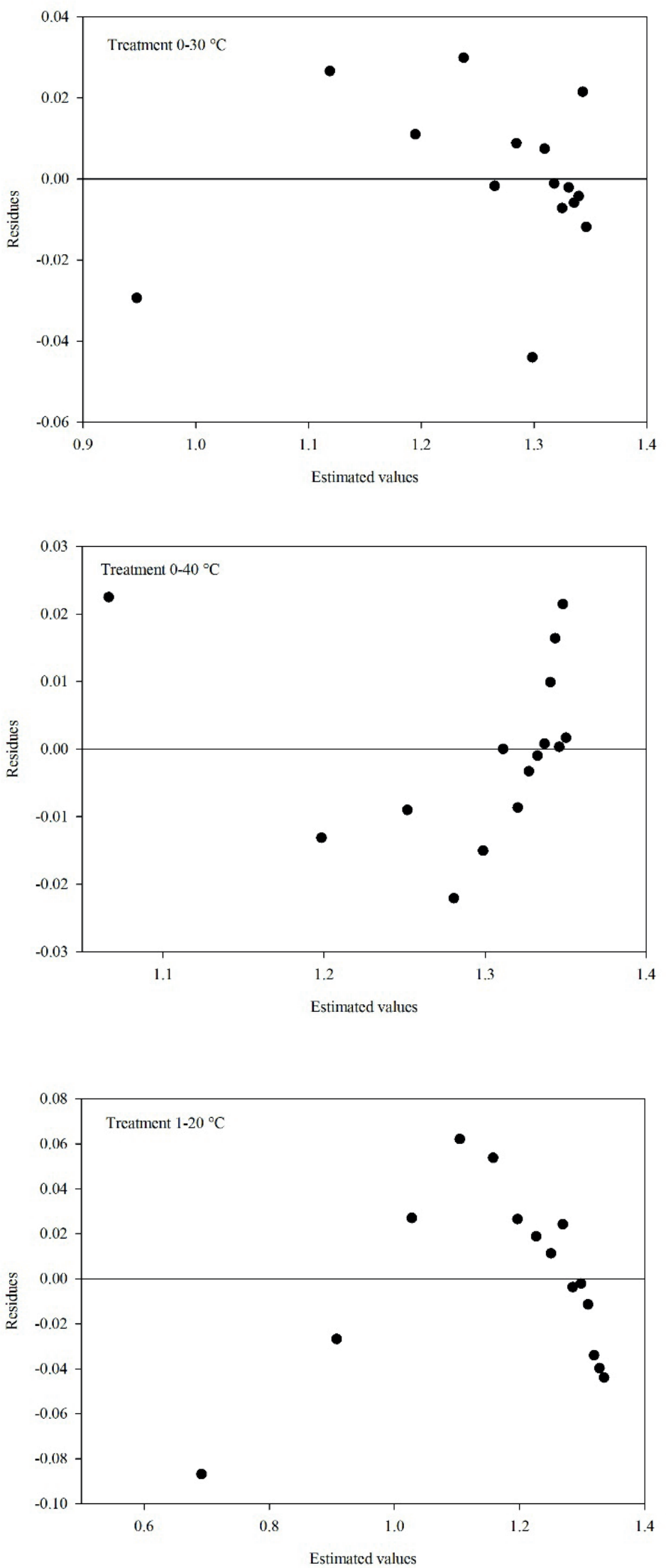

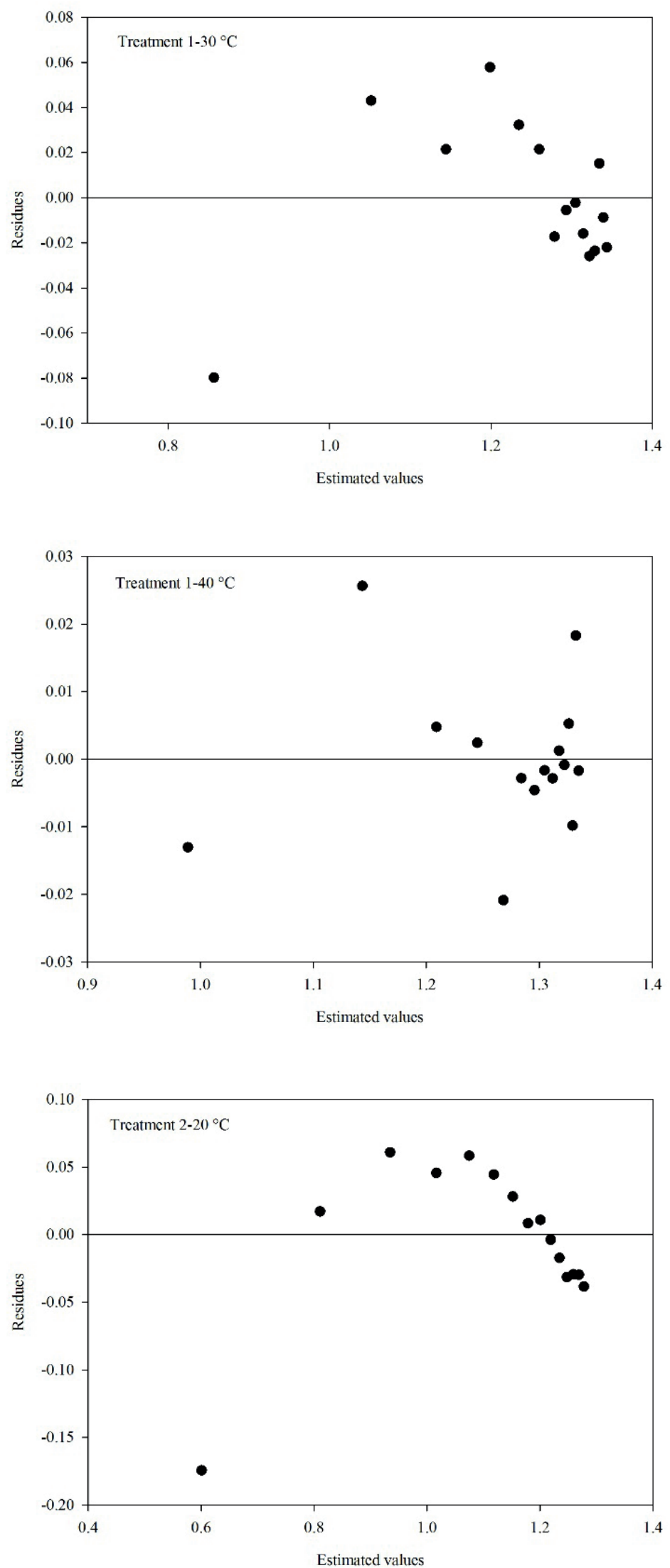

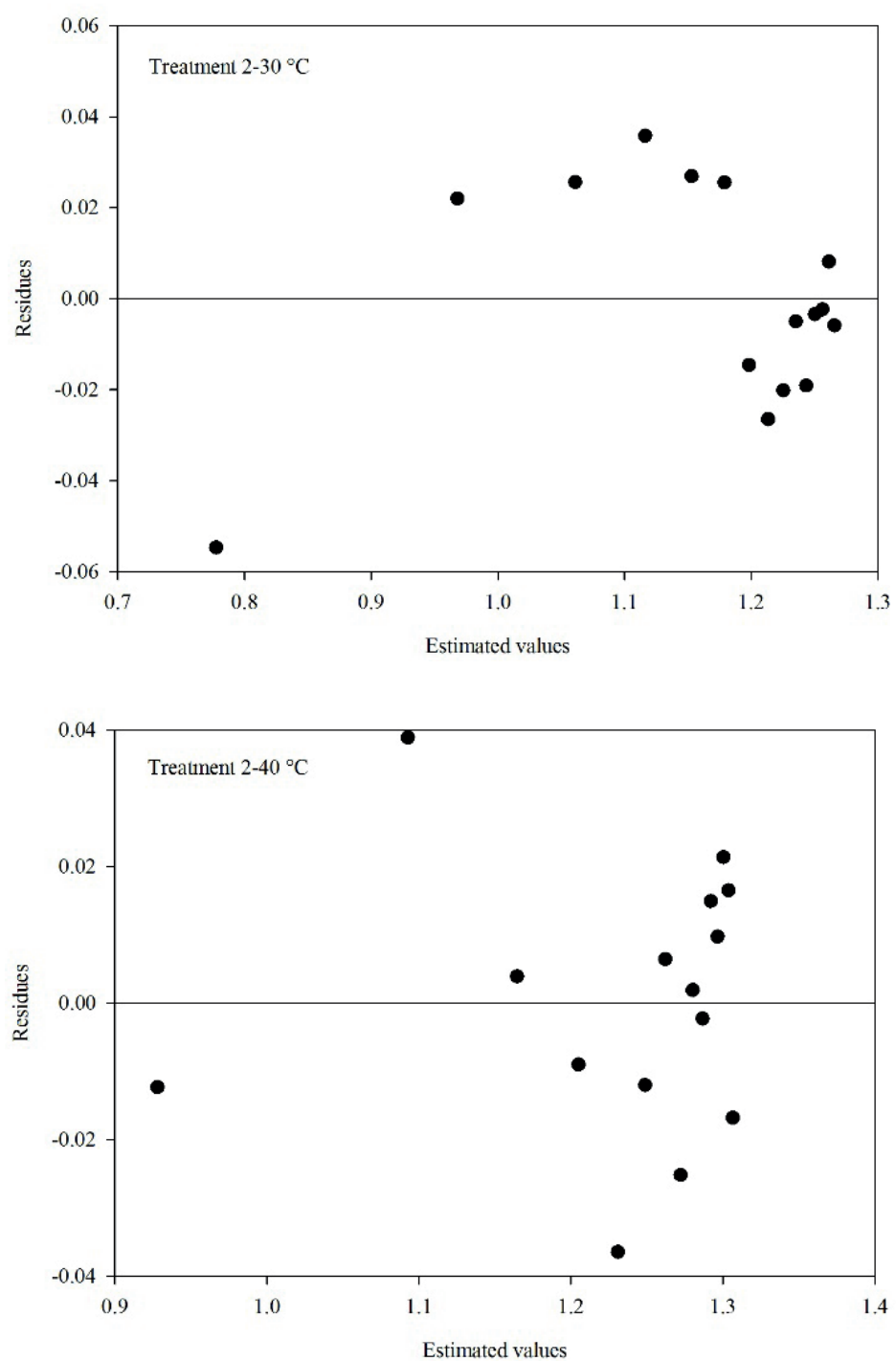

Table 2. Average estimated error (SE), average relative error $(\mathrm{P})$, coefficient of determination $\left(\mathrm{R}^{2}\right)$ and coefficients ( $\alpha$ and $\mathrm{k}$ ) of the Mitscherlich model obtained by the adjustment to the experimental data of the hydration of the bean grains, at different temperatures, for treatments 0,1 , and 2 .

\begin{tabular}{ccccccc}
\hline Sample & $\begin{array}{c}\mathrm{T} \\
\left({ }^{\circ} \mathrm{C}\right)\end{array}$ & $\begin{array}{c}\alpha \\
(\text { decimal, d.b. })\end{array}$ & $\begin{array}{c}\mathrm{k} \\
\left(\mathrm{s}^{-1}\right)\end{array}$ & $\mathrm{SE}$ & $\begin{array}{c}\mathrm{P} \\
(\%)\end{array}$ & $\mathrm{R}^{2}$ \\
\hline \multirow{3}{*}{ Treatment 0} & 20 & $1.289323^{* *}$ & $0.702329^{* *}$ & 0.018 & 1.37 & 0.9897 \\
& 30 & $1.308164^{* *}$ & $1.114499^{* *}$ & 0.035 & 2.31 & 0.9076 \\
& 40 & $1.319671^{* *}$ & $1.572409^{* *}$ & 0.043 & 2.68 & 0.7041 \\
\hline \multirow{3}{*}{ Treatment 1} & 20 & $1.284262^{* *}$ & $0.590782^{* *}$ & 0.015 & 1.13 & 0.9944 \\
& 30 & $1.300713^{* *}$ & $0.882003^{* *}$ & 0.025 & 1.48 & 0.9720 \\
& 40 & $1.300490^{* *}$ & $1.281183^{* *}$ & 0.036 & 2.33 & 0.8778 \\
\hline \multirow{2}{*}{ Treatment 2 } & 20 & $1.225876^{* *}$ & $0.513848^{* *}$ & 0.018 & 1.37 & 0.9897 \\
& 30 & $1.222316^{* *}$ & $0.828341^{* *}$ & 0.035 & 2.31 & 0.9076 \\
& 40 & $1.268612^{* *}$ & $1.175124^{* *}$ & 0.043 & 2.68 & 0.7041 \\
\hline
\end{tabular}

${ }^{* *}$ p-value $<0.0001$ (probability of null hypothesis being true). 
Figure 3. Residue distribution of the Mitscherlich model for bean grains at different hydration temperatures for treatments 0,1 , and 2 .
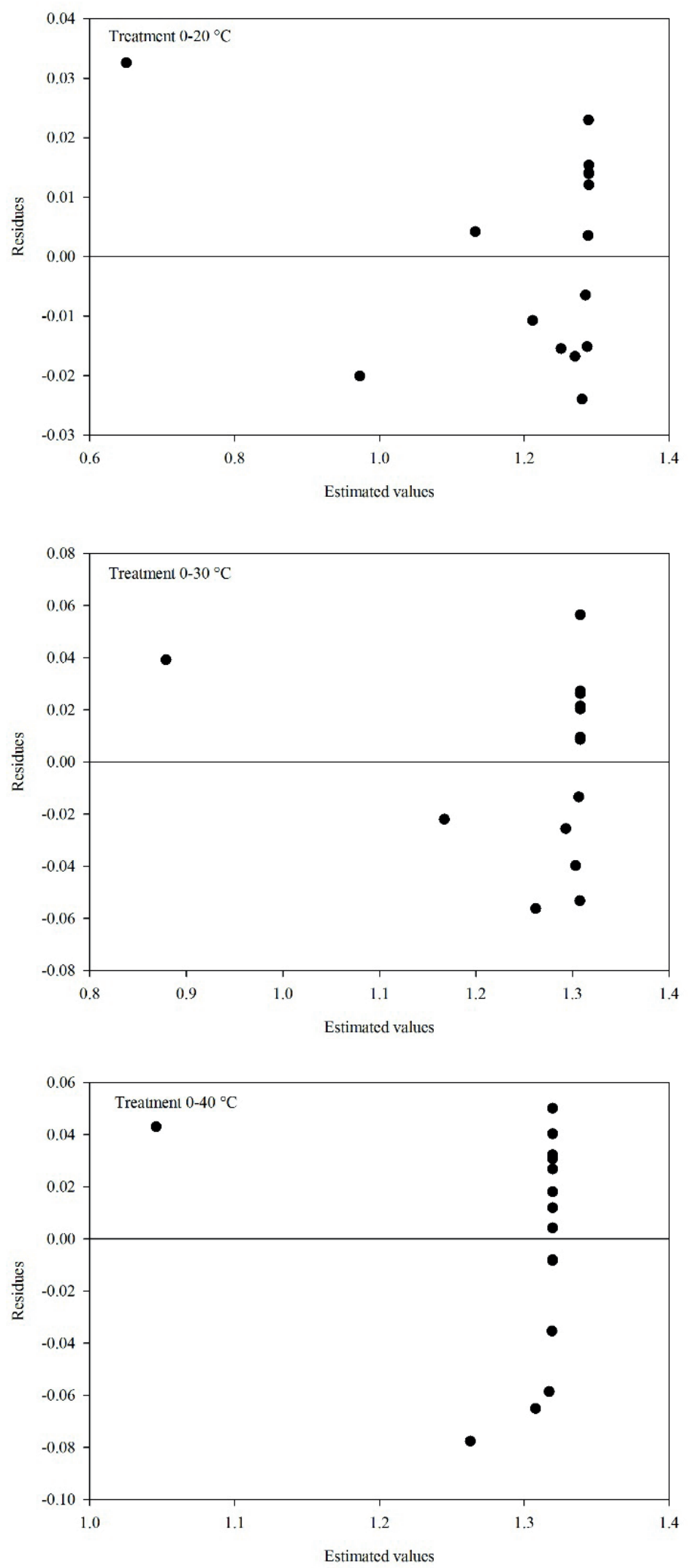

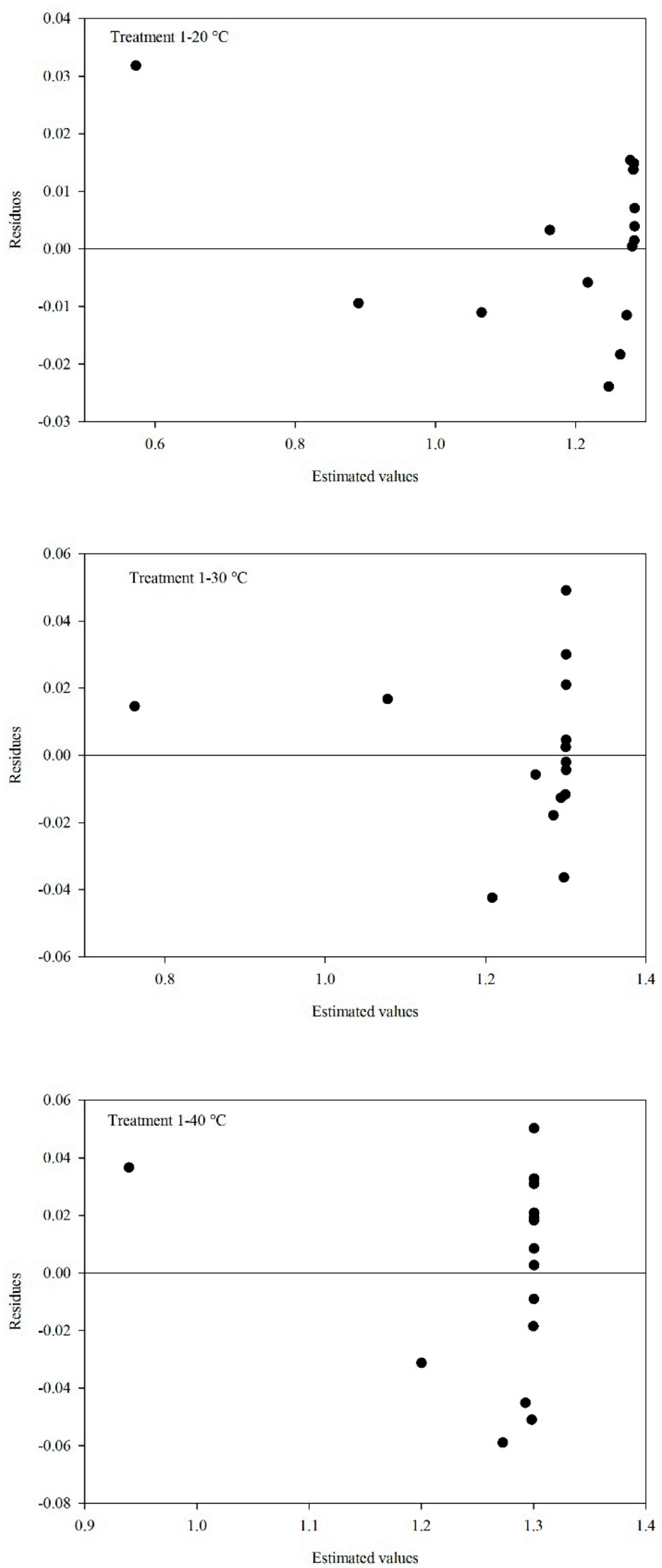

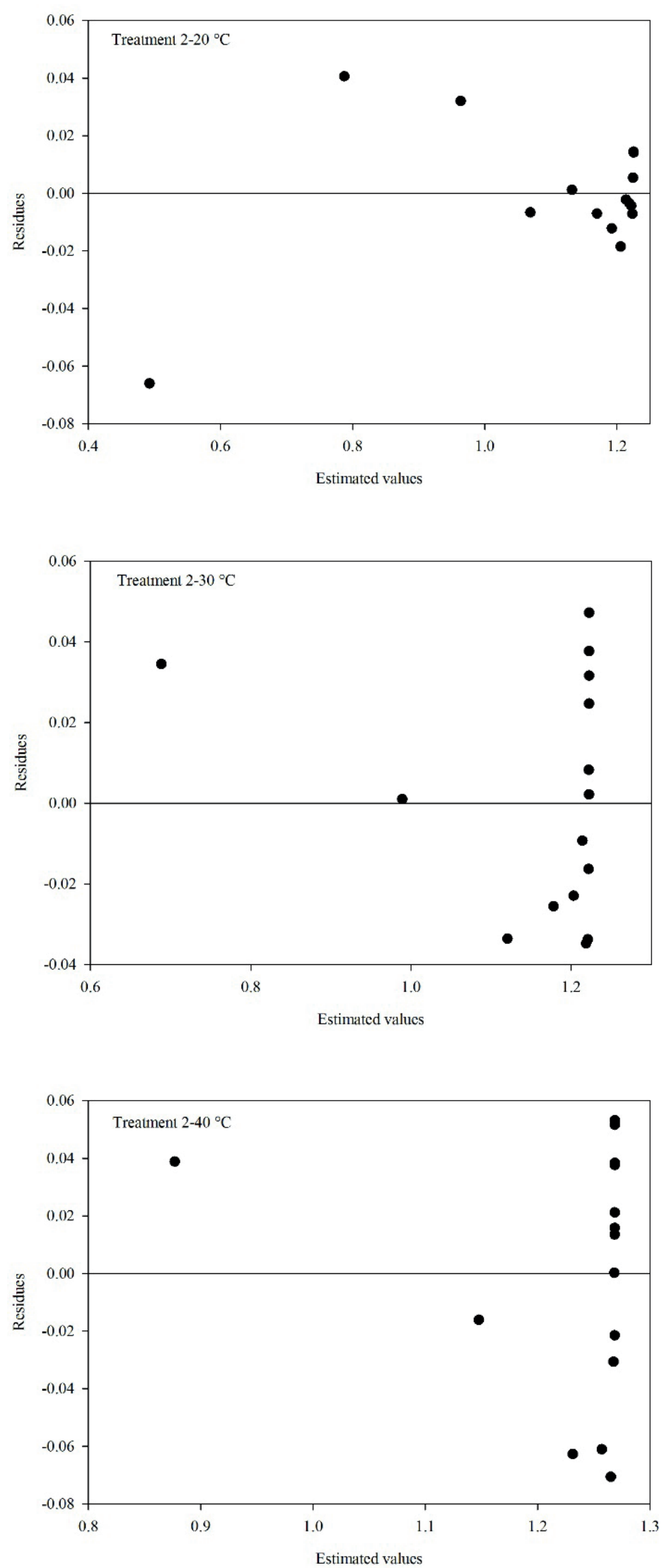
Table 3 presents the adjusted equations of the temperature with its determination coefficients. Peleg model's constants as a result of the hydration They show a good adjustment.

Table 3. Equations for the representation of the Peleg model's constants as result of the hydration temperature for the bean grains in the treatments 0,1 , and 2 and their respective determination coefficients.

\begin{tabular}{ccc}
\hline Sample & Equations & $\mathrm{R}^{2}$ \\
\hline \multirow{2}{*}{ Treatment 0 } & $C_{1}=-0,0328 \times T+1.5720$ & 0.9468 \\
& $C_{2}=-0,0017 \times T+0.7836$ & 0.9450 \\
\hline \multirow{2}{*}{ Treatment 1 } & $C_{1}=-0,0398 \times T+1.9541$ & 0.9684 \\
& $C_{2}=-0,0027 \times T+0.7407$ & 0.9987 \\
\hline Treatment 2 & $C_{1}=-0,0524 \times T+2.4978$ & 0.9495 \\
& $C_{2}=-0,0024 \times T+0.7660$ & 0.5720 \\
\hline
\end{tabular}

\section{Conclusion}

The increase in temperature resulted in an increase in the rate of water absorption by the bean grains, regardless of the treatment; the temperature of $40{ }^{\circ} \mathrm{C}$ was the condition in which there was a higher rate of water absorption, which was independent of the evaluated treatment. The increase in the dosage of the carnauba wax decreased the rate of water absorption by the bean grains, and this effect was more evident in treatment 2. The Peleg model was satisfactorily suitable to the experimental data of the hydration of bean grains of the BRSMG Majestoso variety of the Carioca group. The constants $\mathrm{C}_{1}$ and $\mathrm{C}_{2}$ of the Peleg model exhibited opposite behaviors when the hydration temperatures increased - the first one decreased and the second increased for all the treatments. The Mitscherlich model was not able to describe the process of water hydration of bean grains.

\section{Acknowledgment}

The authors thank Fapemig and Epamig for their financial support.

\section{References}

BELLO, M.; TOLABA, M. P.; SUAREZ, C. Factors affecting water uptake of rice grain during soaking. $L W T$ - Food Science and Technology, Zurique, v. 37, n. 8, p. 811-816, 2004.

BEWLEY, J. D.; BLACK, M. Seeds: physiology of development and germination. $2^{\text {th }}$ ed. New York: Plenum Press, 1994. 445 p.

BOTELHO, F. M.; CORRÊA, P. C.; GONELI, A. L. D.; MARTINS, M. A.; BAPTESTINI, F. M. Análise da hidratação do arroz na parboilização (Analysis of rice hydration in parboiling). Ciência Tecnologia de Alimentos, Campinas, v. 30, n. 3, p. 713-718, 2010.

BOTELHO, F. M.; CORRÊA, P. C.; MARTINS, M. A.; BOTELHO, S. C. C.; OLIVEIRA, G. H. H. Effects of the mechanical damage on the water absorption process by corn kenel. Food Science and Technology, Campinas, v. 33, n. 2, p. 282-288, 2013.

CÂMARA SETORIAL DA CARNAÚBA. A carnaúba: preservação e sustentabilidade. Câmara setorial da carnaúba. Fortaleza: Câmara Setorial de Carnaúba, 2009. $40 \mathrm{p}$.

CUNNINGHAM, S. E.; MCMINN, W. A. M.; MAGEE, T. R. A.; RICHARDSON, P. S.; Modeling water absorption of pasta during soaking. Journal of Food Engineering, Davis, v. 82, n. 4, p. 600-607, 2007. 
FRACASSO, A. F.; FRIZON, C. N. T.; JORGE, L. M. M.; JORGE, R. M. M. Hydration kinetics of transgenic soybeans. Acta Scientiarum. Tecnology, Maringá, v. 37, n. 1, p. 141-147, 2015.

FRACASSO, A. F.; PERUSSELLO, C. A.; HAMINIUK, C. W. I.; JORGE, L. M. M.; JORGE, R. M. M. Hydration kinetics of soybeans: transgenic and conventional cultivars. Journal of Cereal Science, Londres, v. 60, n. 3, p. 584-588, 2014.

HARMSEN, K. A modified Mitscherlich equation for rainfed crop production in semi-arid areas: 1. Theory. Amsterdã: Netherlands Journal of Agricultural Science, 2000. v. 48 , p. $237-250$.

JIDEANI, V. A.; MPOTOKWANA, S. M. Modeling of water absorption of Botswana bambara varieties using Peleg's equation. Journal of Food Engineering, Davis, v. 92, n. 3, p. 182-188, 2009.

LISBÔA, J. F.; SILVA, J. N.; CAVALCANTI, M. T.; SILVA, E. M. C. A.; GONÇALVES, M. C. Análise da hidratação de grãos de alpiste. Brasileira de Engenharia Agrícola e Ambiental, Campina Grande, v. 19, n. 3, p. 218-223, 2015.

MUÑOZ, I.; GARCIA-GIL, N.; ARNAU, J.; GOU, P. Rehydration kinetics at 5 and $15{ }^{\circ} \mathrm{C}$ of dry salted meat. Journal of Food Engineering, Davis, v. 110, n. 3, p. 465471, 2012.

OMOTO, E. S.; ANDRADE, C. M. G.; JORGE, R. M. M.; COUTINHO, M. R.; PARAÍSO, P. R.; JORGE, L. M. de M. Modelagem matemática e análise da hidratação de grãos de ervilha. Ciência e Tecnologia de Alimentos, Campinas, v. 29, n. 1, p. 12-18, 2009.
PELEG, M. An empirical model for the description of moisture sorption curves. Journal of Food Science, Illinois, v. 52, n. 4, p. 1216-1219, 1988.

RATKOWSKY, D. A. Handbook of nonlinear regression models. Pullman: Washington State University, 1989. v. $107,241 \mathrm{p}$.

RESENDE, O.; CORRÊA, P. C. Modelagem matemática do processo de hidratação de sementes de feijão. Acta Scientiarum. Agronomy, Maringá, v. 29, n. 3, p. 373-378, 2007.

RESIO, A. C.; AGUERRE, R. J.; SUAREZ, C. Hydration kinetics of amaranth grain. Journal of Food Engineering, Davis, v. 72, n. 3, p. 247-253, 2006.

TURHAN, M.; SAYAR, S.; GUNASEKARAN, S. Application of peleg model to study water absorption in chickpea during soaking. Journal of Food Engineering, Davis, v. 53, n. 2, p. 153-159, 2002.

VENGAIAH, P. C.; RAIGAR, R. K.; SRIVASTAV, P. P.; MAJUMDAR, G. C. Hydration characteristics of wheat grain. Agricultural Engineering International: CIGR Journal, Pequim, v. 14, n. 1, p. 116-119, 2012.

WOODSTOCK, L. W. Seed imbibition: A critical period for successful germination. Journal of Seed Technology, Moline, v. 12, n. 1, p. 1-15, 1988.

YILDIRIM, A.; ÖNER, M. D.; BAYRAM, M. Fitting Fick's model to analyze water diffusion into chickpeas during soaking with ultrasound treatment. Journal of Food Engineering, Davis, v. 104, n. 1, p. 134- 142, 2011.

Modeling of water absorption of ultrasound applied chickpeas (Cicer arietinum L.) using Peleg's equation. Journal of Agricultural Sciences, Toronto, v. 16, n. 4, p. 278-286, 2010. 
